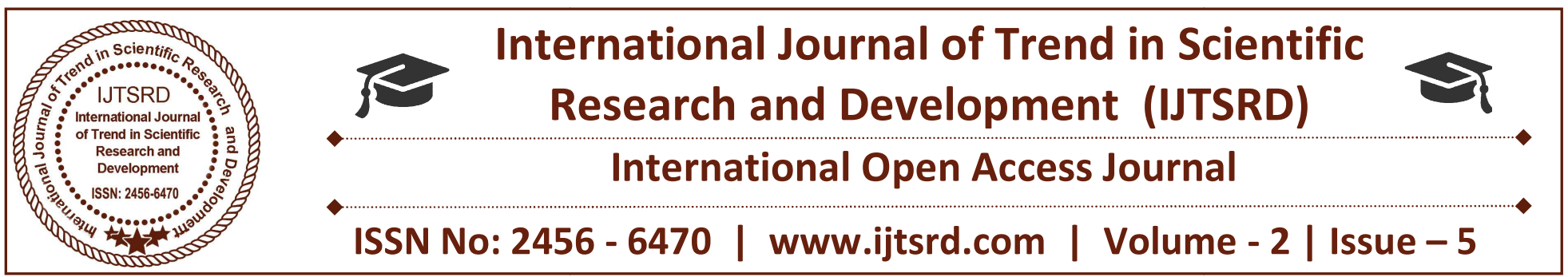

\title{
Penal Employment Indemnity Bond; Antithesis to Freedom of Parties
}

\author{
Akshansh Singh \\ B.B.A., LL.B (Hons), Indore Institute of Law \\ Indore, Madhya Pradesh, India
}

\section{INTRODUCTION}

\section{What is Indemnity?}

According to sec.124 of Indian contract act,"A contract of indemnity is a contract by which one party promise to save the other from the loss caused to him by the conduct of the promisor himself or by the conduct of any other person." The person who promises to make good the loss is called the 'indemnifier' and the person to whom the promise is made i.e. called the 'indemnified' or the indemnityholder'

EX:- sanjay parked his scooter at the collage stand. $\mathrm{He}$ lost his token given by the scooter stand contractor. The stand contractor refuse to return the scooter to sanjay unless he (sanjay)given him an indemnity bond against any loss which he may if any other person claim the scooter from the contractor

It is important to note that definition given in section 124 is very narrow. It include only:

$>$ Express promises to indemnity and

$>$ Loss caused by the promisor or any other person

It does not include

$>$ Implied promises to indemnity and

$>$ Loss caused by accident and event which do not depend upon the conduct of the promisor or any other person

\section{Indemnity bond}

Indemnity bond or undertaking is a really a misnomer for the most document of this nature requires the employee to compensate the holder for the loss, predetermined, incurred by the holder as a result of action of the issuer re any other person. Such a contract is governed by the Indian contract act, 1872 and comes under the purview of section 74 of the said act, which provides for compensation for breach by way of liquidated damages. Liquidated damages is a sum pre-agreed between parties to a contract to be paid by the breaching party irrespective of whether actual damages has been incurred by the nonbreaching party as a genuine pre-estimated of damages.

By executing the bond the employees agrees to remain in the services of the employer for a fixed duration. The employees may leaves the employers services earlier by tendering his resignation, but in doing so he is obliged to compensation the employer with the amount specified in bond.

Section 74 require the compensation amount claimed either by way of damages or penalty to be reasonable. Exorbitant compensation, even though agreed by the employee, will not be enforceable. The compensations amount must be in accordance with the benefit provided to the employee and the loss and inconvenience caused to the organization as a result of the employee's premature exist from the organization.

While the court have never gone into the question of whether an indemnity bond which impose excessive amount of liquidated damages/ penalty is in fact in restraint of trade, the supreme court has held in the past that neither the test of reasonable are application to case governed by section 27 of the contract act, unless it falls within exception 


\section{Indemnify and and Indemnification}

To indemnify someone is to absolve that person from responsibility for damage or loss arising from a transaction.

Indemnification is the act of not being held liable for or being protected from harm, loss, or damages, by shifting the liability to another party. Both terms relate to liability, specifically being sued for one's actions.

\section{Indemnity - Variations in Meaning}

\section{Indemnity}

Also includes an understanding that an injured party has a right to claim reimbursement or compensation for a loss or damage from the person who has the duty. This concept is seen often in civil lawsuits relating to negligence claims.

\section{Indemnity}

Refers in some contexts as compensation for loss or damage from the actions of another party.

\section{Indemnity}

Can also refer to a legal exemption from loss or damages, as in the case of an indemnity clause in a contract, in which one party agrees to take the liability for loss or damage from another party. In this case, indemnity has the general meaning of "hold harmless."

\section{No Indemnity for Illegal Activities}

A person can attempt to be indemnified (held harmless) for doing their duty or acting within the scope of of their job.

But indemnity doesn't carry over into illegal acts, like theft, harassment, and fraud. For example, a corporate financial officer may have made a mistake in an important financial report. The officer may be protected from being sued for this mistake. But if the financial officer embezzles money from the company, this is a crime and there's no indemnity protection.

\section{Indemnity and Hold Harmless Agreements and State Laws}

An indemnity agreement is sometimes called a hold harmless agreement, because it is an attempt to make sure that one party does not attempt to sue another party for negligence.
At present, 42 states have some kind of state laws that limit the inclusion of indemnity clauses or agreements. While indemnity agreements are a protection against lawsuits, they don't allow compensation for loss or damage.

Even where these clauses are not restricted, courts have held that indemnity clauses must be expressed in "clear and unequivocal terms" (Maine) or, "very clearly intended" (Nevada).

\section{Indemnity and Contracts}

Indemnity usually arises in contracts, either as a separate indemnity agreement or as an indemnity clause in a contract. This language is included in cases where there is a possibility of loss or damage to one party during the term of, or arising from the circumstances of, the contract. The right to indemnity and the duty to indemnify ordinarily stem from a contractual agreement, which generally protects against liability, loss, or damage.

\section{Uses of Indemnity Agreements in Business}

\section{Indemnity in construction contracts.}

Indemnity clauses or agreements in construction contracts are an attempt to protect the contractor from lawsuits and losses due to negligence.

\section{Some states}

\section{Indemnity and Insurance}

One of the best examples of indemnity is insurance, which an insurance company indemnifies a property owner from losses or damage to that property. The business owner basically transfers the risk of having to pay for negligence to the insurance company.

In another example, business owners may buy indemnity insurance for professional liability. Allena Tapia, of TheBalance, explains how the concept of indemnity insurance can protect freelance writers.

\section{Examples of Indemnity Clauses in Contracts}

Example 1: Here is an example of a simple indemnity clause in a contract:

"I hereby release, acquit and discharge [company] and its agents and employees from any liability arising from any circumstance including the negligence of [company] or its employees. 
Example 2: Many states include an indemnity clause in the template for articles of incorporation (the document used to register a corporation with a state).

These standard indemnity clauses seek to protect the corporation's directors, executives, employees, and agents. A sample indemnity clause might state But a typical indemnity clause may also state that these individuals aren't entitled to indemnity for liability for gross negligence, willful misconduct, or breach by the individual of any provisions of the agreement.

\section{Liability under the employment and indemnity concept}

An unlawful, or un-contractual, order by the charterer will be a breach of contract because he is not entitled to give it under the contract;

For example, an order to proceed to an unsafe port (The Kanchenjunga2, see later); an order to sign a bill of lading the terms of which are not consistent with the terms of the $\mathrm{c} / \mathrm{p}$ (Kruger $\mathrm{v}$ Moel3: no incorporation in $b / 1$ of the $\mathrm{c} / \mathrm{p}$ exclusion from liability clause); an order to deliver cargo without presentation of bill of lading (The Houda4) 0 The remedy for loss caused to the owner is dealt with either by an express or implied indemnity. Damages for breach are an alternative remedy.

Under this concept, the owner's right to indemnity may also arise when the order is contractual but, nevertheless, causes loss to the owner by reason of compliance with the charterer's order (The Island Archon5).

Indemnity means compensation for all loss caused by compliance with the charterer's order provided the chain of causation is not broken.

\section{Scope of the employment clause under time charters}

Employment embraces economic aspects, namely the exploitation of the earning potential of a vessel by the charterer. Crucial to the bargain for him are the terms which require the master to prosecute voyages with utmost despatch, which provide that the master shall be under the orders and directions of the charterer as regards employment (The Hill Harmony10).
A time charterer employs the ship not the crew, who remain the employees of the owner. The master, who is under the charterer's orders, has an obligation to obey the orders, unless he knows they are unlawful, in a sense of being un-contractual. In such a case, the owner, through the master, has a right of election either to reject or accept the order (see later). The orders which come within the scope of employment must be concerning the services of the ship not matters of navigation.

Negative covenants in an employment contract

Agreement or contract preventing, the one agreeing, from doing certain activities is a negative covenant. Negative covenants in employment contracts largely include the ones which restrict the employees from working for other organisations involved in similar business, during the course of employment and some even after the course of employment. It would also include restrictions on employees from terminating the employment prior to the expiry of a specified period of time.

Employers include negative covenants in the employment agreement for the purpose of protecting the trade secrets of the organisation. A negative covenant will prevent the employee from using the confidential or proprietary information acquired by him and/or the skill sets developed in the course of his employment for his personal gain.

On the other hand, these tactics can be said to evidence the dominating position of the employer in the contract of employment. Such covenants are often perceived as restrictions on an employees' freedom to profess any profession under article 19 (1) (g) of the Constitution of India.

The Supreme Court[1] has observed that a negative covenant is generally valid during the course of employment. It implies 'a servant's duty of fidelity.' A restriction of this sort is held as reasonable and valid in law.

While certain negative covenants are valid in law, a clause restricting the employee from taking up a career or job of his choice, which exceeds the course of employment or in other words which operates even after the termination of employment, may not be enforceable in a court of law. The Madras High Court has observed in Dr. S. Gobu v. State of Tamil Nadu[2] that a negative covenant that operates after the termination of the employment is generally regarded 
as a restraint to trade practices under section 27 of the Indian Contract Act, 1872.[3] For a detailed discussion on restraint of trade please see our previous blog post on this subject.

Unlike other jurisdictions in India, there is no protection offered to any restraint, whether or not such restraint is reasonable as to the time period after completion of employment or the geography where such limitation operates.

\section{Judicial pronouncements on this point}

The Supreme Court has not thus far reviewed and responded to a question on validity of fixed period contract with an employee. However in a 2013[4] judgment the Supreme Court had extended the validity of a study bond which was not honoured by a lecturer and awarded reasonable damages to the employer. This case can be distinguished on the fact that the government servant was sent for study with full pay and other service conditions and he did not bother to complete his course. The Supreme Court while frowning upon the attitude of the employee did not however enforce the indemnity bond to its fullest extent.

In recent case before the Bombay High Court[5], the Hon'ble Court, set aside 3 awards passed in three separate arbitrations in favour of Godrej Infotech Limited. The Bombay High Court found no merit in the case of the company against employees who did not serve the stipulated period of 2 years under the employment bond as it was found that no specialised training was given to employees. The training provided by the company was not of a specialised nature and was a general training of about 5 days in all.

The Bombay High Court however refrained from going into the legality of such employment bonds.

In the case of Scipa India Limited v. Manas Pratim Deb[6] before the Delhi High Court, the Respondent had signed some bonds in the course of his employment with the Plaintiff. As per the bonds, the Respondent was bound to serve for five years or pay a sum of Rs.2 lakhs per bond, if he left the service before the period of bond ended. The Respondent resigned three years prior to the expiration of the second bond and a few months prior to the expiration of the first bond. The Plaintiff claimed two lakhs each for both the bonds and other Rs.17, 290 as notice period money plus a certain sum as medical expenses.
The trial court dismissed the suit and awarded an adjusted compensation of Rs.44, 300. An appeal was filed before the Delhi High Court for the recovery of the balance amount claimed by the Plaintiff. The learned Judge ruled in favour of the Respondent and dismissed the appeal. The court observed that:

The period of first bond had almost expired, hence claiming Rs.2 lakhs for the same was unreasonable. Hence the bond was unenforceable.

The compensation in regard to the second bond was claimed to be reasonable by the Plaintiff on the basis of contended training given to the Respondent. In absence of any proof to back the contended training, the compensation was viewed as unreasonable. Hence the bond was unenforceable.

The adjusted compensation awarded by the trial court was considered adequate.

The Hon'ble Delhi High Court however refrained from going to the legality of such a bond per se i.e. whether such bonds are at all enforceable

In a case before the Andhra Pradesh High Court[7] the facts varied from the above case. The company provided proper training to the employee who had joined as a trainee and later was absorbed in the company as a software engineer. A bond was signed between the company and the employee by which made the employee liable to pay a sum of Rs.2 lakhs in case he decided to leave the company before the bond period. The court was of the opinion that since the Company had invested time and money in the training of the employee, the compensation under the bond was held to be reasonable. The bond was valid and enforceable.

The Madras High Court[8] has observed that in cases where there is an indemnity bond between the employer and employee, the Court is of the opinion that though a clause in an employment agreement obliges the employee to work for the organization for a fixed period of time, paying compensation and leaving the organization makes that obligation disappear. If the employee leaves the service abruptly by handing in his resignation, he will be bound by the agreement or bond and will be liable to pay to the organization the damages as per the agreement. 